If you do not need this publication after it has gerved your purpose, please return it to the Geological Survey, using the official mailing label at the end

UNITED STATES DEPARTMENT OF THE INTERIOR

ADDITIONS TO THE WILCOX FLORA FROM KENTUCKY AND TEXAS

GEOLOGICAL SURVEY PROFESSIONAL PAPER 193-E 


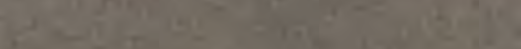

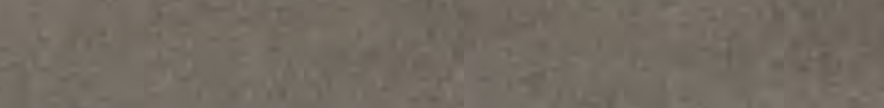

495

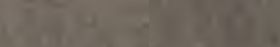

A S.

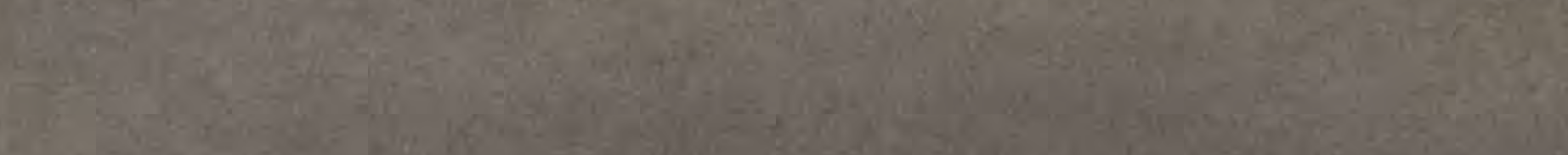

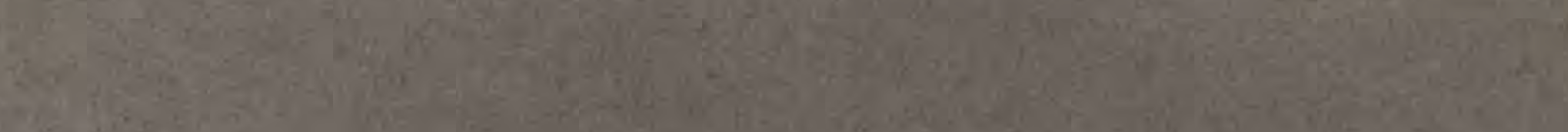

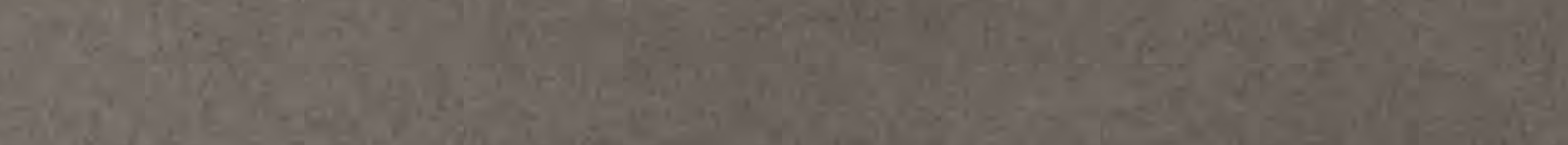

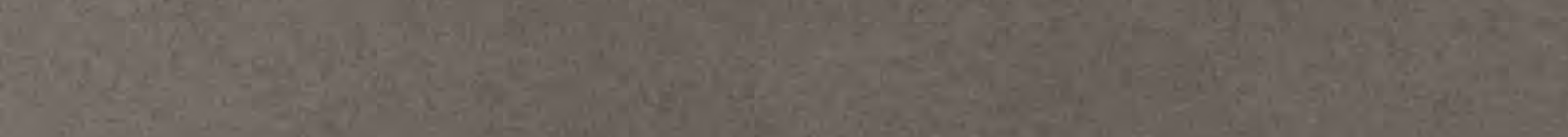

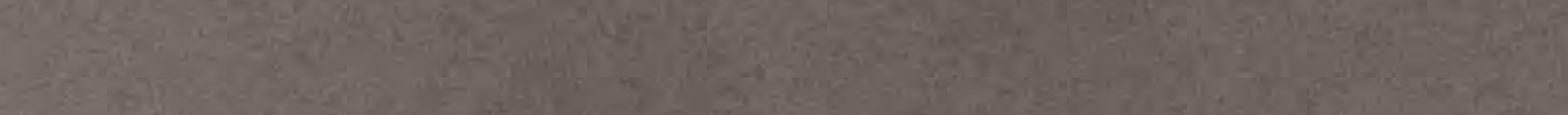
Wit.

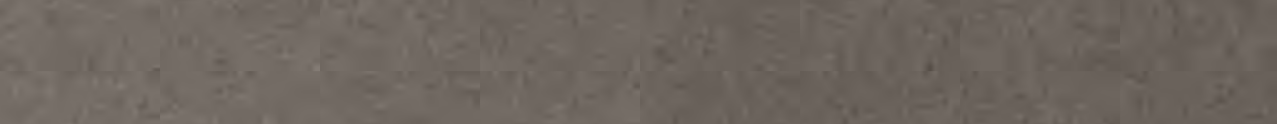

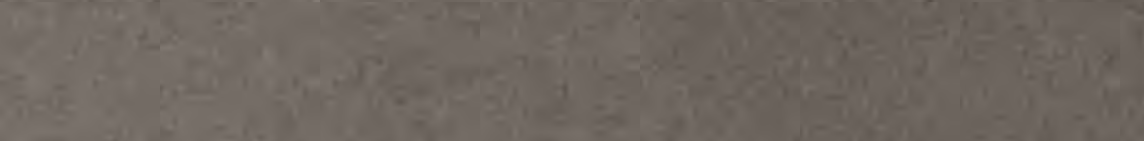

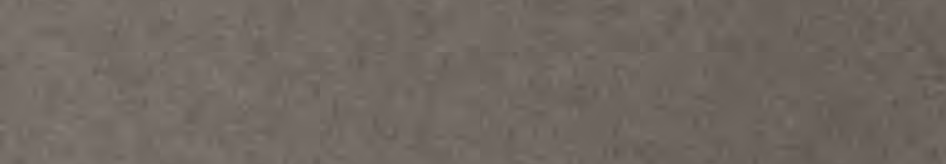

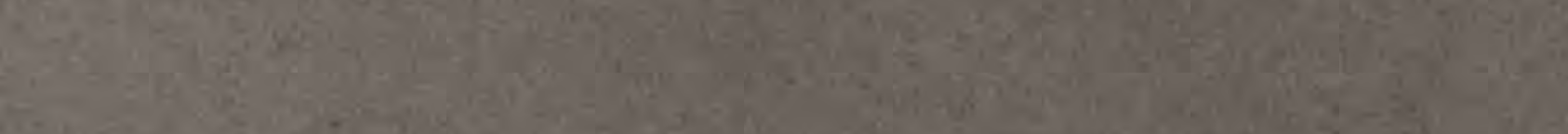

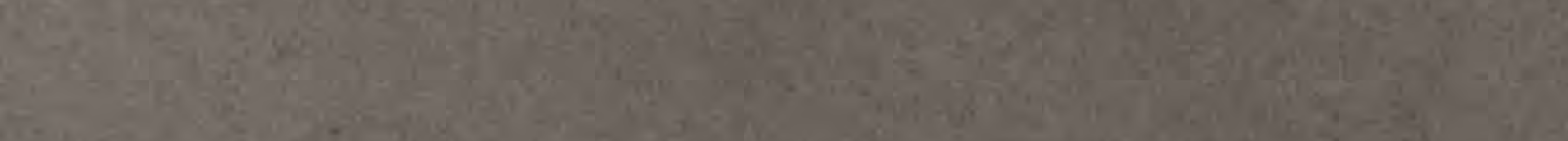

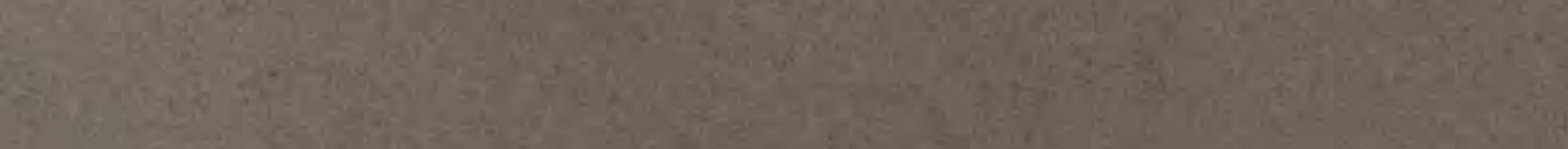
$2 / r$

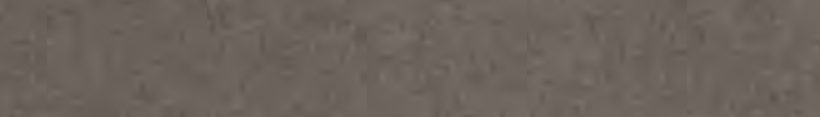
26.

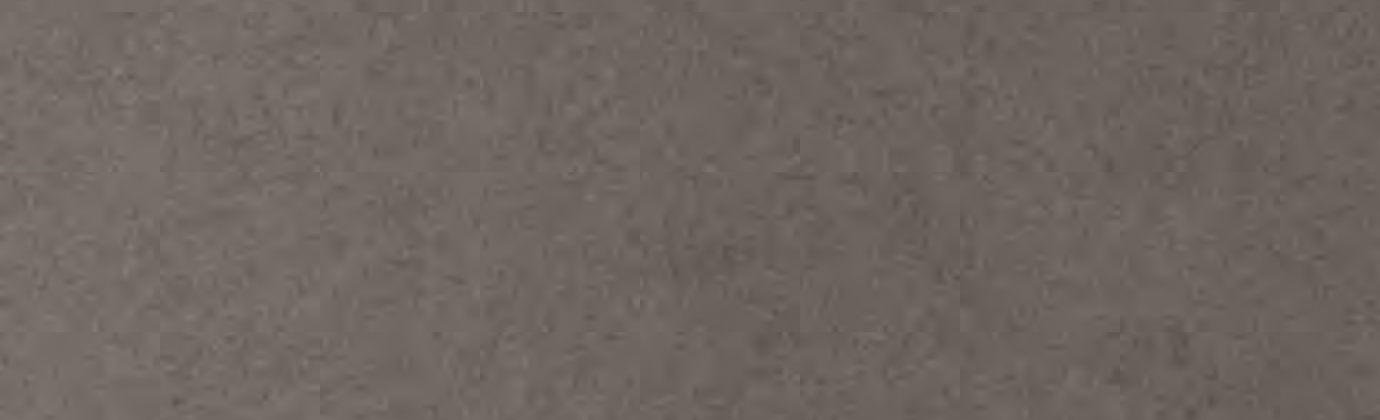

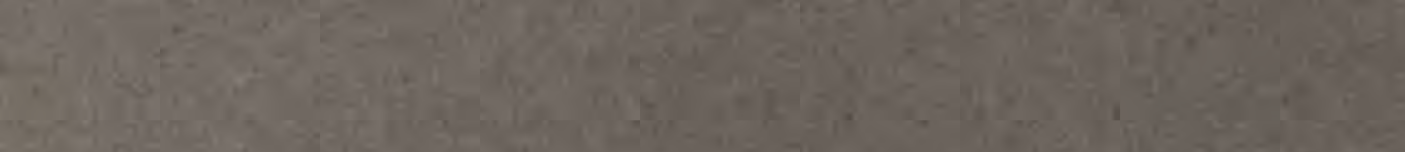
ris $-9 x$

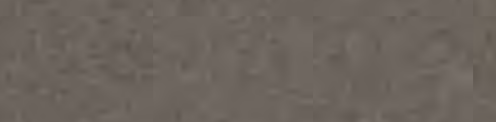

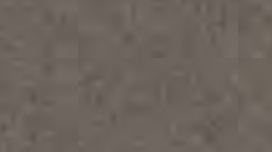
a

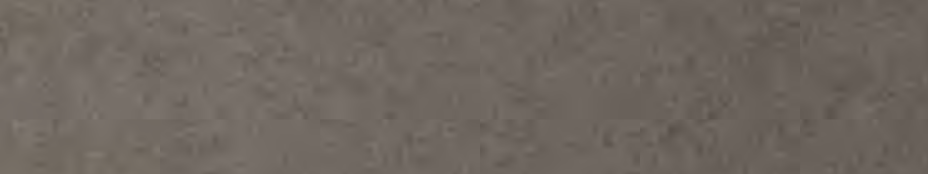

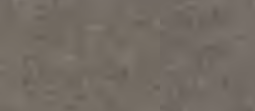

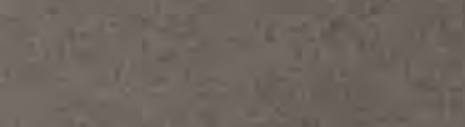

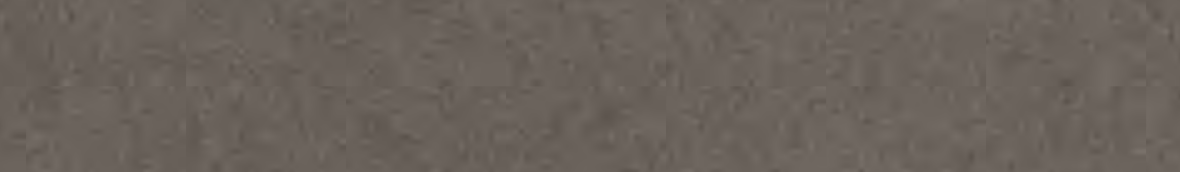

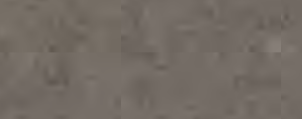
$-4056$ rest

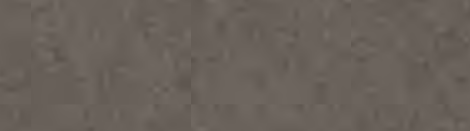
15. $3+x^{2}-1$ 
UNITED STATES DEPARTMENT OF THE INTERIOR

Harold L. Ickes, Secretary

GEOLOGICAL SURVEY

W. C. Mendenhall, Director

Professional Paper 193-E

\title{
ADDITIONS TO THE WILCOX FLORA FROM KENTUCKY AND TEXAS
}

\author{
BY \\ EDWARD W. BERRY
}

Shorter contributions to general geology, 1938-40

(Pages 83-99)

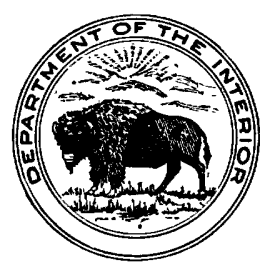

UNITED STATES

GOVERNMENT PRINTING OFFICE

WASHINGTON : 19.11

For sale by the Superiutendent of Documents, Washington, D. C. . . . - . - Price 15 cents 


\section{CONTENTS}

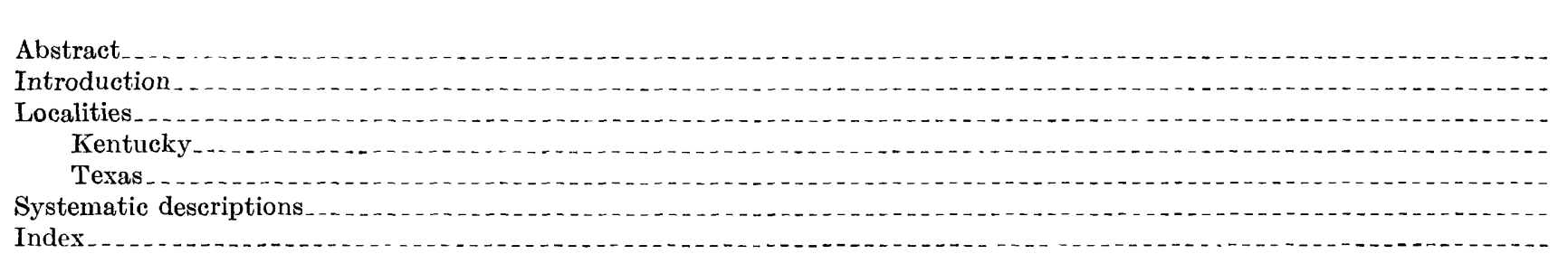

Abstract

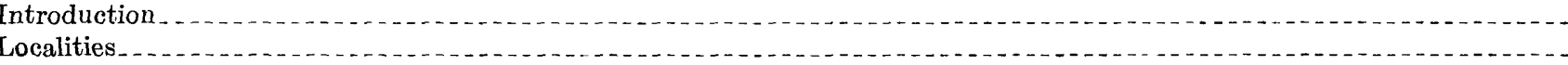

Kentucky_ _

Systematic descriptions

Index $\ldots \ldots \ldots$

\section{ILLUSTRATIONS}

Plates 20-24. Additions to the Wilcox flora from Kentucky and Texas 


\title{
ADDITIONS TO THE WILCOX FLORA FROM KENTUCKY AND TEXAS
}

\author{
By Edward W. Berry
}

\begin{abstract}
Five new species from localities in Texas and four from localities in Kentucky are described in this paper. A number of previously known species are also discussed or figured.

\section{INTRODUCTION}

Since the manuscript of Professional Paper $156^{1}$ was submitted for publication the writer has received considerable additional material on the Wilcox flora from various sources. By far the largest amount was collected in western Kentucky by Prof. Joseph K. Roberts, of the University of Virginia, during the summer of 1929. As the Wilcox flora is unique not only in the number and variety of its botanical types, but in the excellence of their preservation, it would seem desirable to bring the literature on it up to date insofar as the material in the hands of the writer is concerned, especially as all this material has now been transferred to the Geological Survey and is stored in the National Museum. The present paper attempts this and, after listing the species occurring at scattered localities from Kentucky to Texas, discusses and figures a limited number of new or noteworthy species.
\end{abstract}

\section{LOCALITIES}

\section{KENTUCKY}

Fossil plants were first discovered in Kentucky over 50 years ago at Wickliffe, in Ballard County, by R. H. Loughridge, and 12 species were identified by Lesquereux. I visited the region in 1913 and recorded 28 species in 1916. ${ }^{2}$ The collections made by Joseph K. Roberts represent the following plant species, associated with which are the shells of small Unionidae and caddis worm cases (Folindusia):

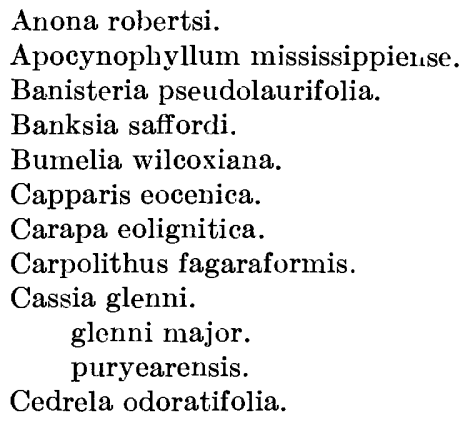

${ }^{1}$ Berry, E. W., Revision of the lower Eocene Wilcox flora of the Southeastern States, with descriptions of new species, chiefly from Tennessee and Kentucky: U. S. Geol. Survey Prof. Paper 156, 196 pp., 1930.

? Berry, E. W., The lower Eocene floras of southeastern North America: U. S. Geol. Survey Prof. Paper 91, pp. 51, 52, 1916.
Celastrocarpus eocenicus.

Dalbergia eocenica.

Dryophyllum puryearense. tennesseense.

Drypetes prelateriflora.

Ficus puryearensis.

Leguminosites drepanocarpoides.

Magnolia angustifolia. leei.

Mespilodaphne eolignitica.

Mimosites lanceolatus. variabilis.

Mimusops eolignitica.

Myrcia bentonensis. wortheni.

Nectandra pseudocoriacea. wilcoxensis.

Palaeodendron americanum.

Persea wilcoxiana.

Poacites sp.

Reynosia praenuntia longepetiolata.

Sabalites grayanus.

Sapindus eoligniticus.

formosus.

knowltoni.

linearifolius. mississippiensis.

Sophora mucronata.

Schefflera? elliptica.

The following are figured without discussion: $D_{i} y$ ophyllum puryearense ( $\mathrm{pl}$. 20, fig. 1), Magnolia leei Knowlton (pl. 20, fig. 2), Anona robertsi Berry (pl. 23, fig. 11), and Cassia puryearensis Berry (pl. 23, fig. 21).

The locality at Boaz, in Graves County, was also discovered by Loughridge, and his collections were studied by Lesquereux. In 1930 I recorded six species from this locality. ${ }^{3}$ Following are the forms recognized in the Roberts collection, which brings the total to 44 species:

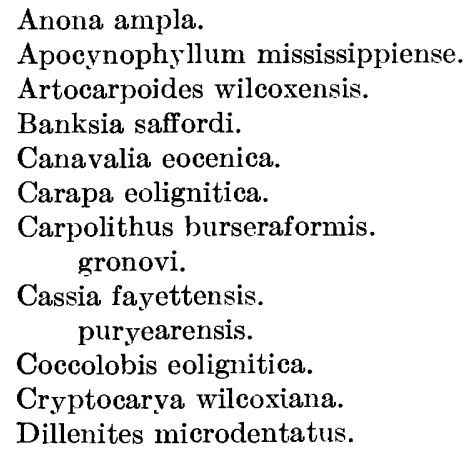

Anona ampla.

Apocynophyllum mississippiense.

Artocarpoides wilcoxensis.

Banksia saffordi.

Canavalia eocenica.

Carapa eolignitica.

Carpolithus burseraformis. gronovi.

Cassia fayettensis. puryearensis.

Coccolobis eolignitica.

Cryptocarya wilcoxiana.

Dillenites microdentatus.

3 Berry, E. W., Revision of the lower Eocene Wilcox flora of the southeastern States, with descriptions of new species, chiefly from Tennessee and Kentucky: U. S. Geol. Survey Prof. Paper 156, 196 pp., 1930. 
Diospyros wilcoxiana.

Dryophyllum puryearense. tennesseense.

Engelhardtia ettingshauseni.

Euonymus splendens.

Ficus myrtifolia. pseudolmediafolia.

Gleditsiophyllum eocenicum.

Heisteria sapindifolia.

Juglans schimperi.

Laguncularia preracemosa.

Magnolia angustifolia.

Mespilodaphne coushatta.

Metopium wilcoxianum.

Mimosites variabilis.

Mimusops eolignitica.

Myrcia vera.

wortheni.

Myrica elaenoides?

Nectandra lancifolia. puryearensis.

Oreodaphne mississippiensis. obtusifolia.

Poacites sp.

Sapindus formosus. linearifolius.

Schefflera formosa.

Sideroxylon ellipticus.

Sophora wilcoxiana.

The third locality, which was discovered by Roberts, is Viola, in Graves County, just south of Boaz. The following 75 species are contained in the Roberts collection:

Anacardites puryearensis.

Anona eolignitica.

An tholithes amentiferus.

Apocynophyllum mississippiense. mississippiense ovatum. wilcoxense.

Banisteria repandifolia.

Banksia saffordi.

Bombacites eocenicus. cf. catha.

Canavalia acuminata.

Capparis eocenica.

Carapa eolignitica.

Carpolithus puryearensis.

Cassia emarginata. fayettensis. glenni. puryearensis.

Cedrela mississippiensis. odoratifolia. puryearensis.

Celastrus minor. taurinensis. violensis. robertsi.

Chrysobalanus inaequalis.

Combretum wilcoxense.

Dalbergia wilcoxiana.

Diospyros wilcoxiana.

Dodonaea wilcoxiana.

Dryophyllum puryearense. tennesseense.

Drypetes prelateriflora.

Engelhardtia ettingshauseni.
Ficus fructus rostrata. inyrtifolia. pandurifolia. pseudopopulus. puryearensis. tennesseensis. wilcoxensis.

Heisteria sapindifolia.

Heterocalyx saportana. Icacorea prepaniculata.

Ilex eolignitica.

Juglans oceidentalis.

Leguminosites andiraformis.

Melastomites verus.

Meniphylloides tennesseensis.

Mespilodaphne coushatta. eolignitica.

Metopium wilcoxianum.

Mimusops sieberifolia.

Myrica puryearensis.

Nectandra parvula. pseudocoriacea. purvearensis.

Nyssa wilcoxiana.

Oreodaphne mississippiensis.

Paliurus mississippiensis.

Paraengelhardtia eocenica.

Psychotria grandifolia?.

Reynosia praenuntia longepetiolata.

Rhamnites knowltoni.

Rhamnus coushatta.

Sabalites grayanus.

Sapindus eoligniticus. linearifolius. mississippiensis.

Sophora mucronata. repandifolia. wilcoxiana.

Ternstroemites lanceolatus.

Vantanea wilcoxiana.

Folindusia.

A sand grain caddis case.

Figured without discussion are Ficus myrtifolia Berry (pl. 21, fig. 8), Sapindus linearifolius Borry (pl. 23, figs. 13-15), Melastomites verus (Berry) (pl. 23, fig. 18), Celastrus taurinensis Ward (pl. 23, fig. 12), Combretum wilcoxense Berry (pl. 23, fig. 22), the caddis case (pl. 23, fig. 16), and a fish scale (pl. 23, fig. 17).

\section{TEXAS}

In the summer of 1929 I received from Albert J. Kirn, of Somerset, Tex., a considerable collection of Wilcox flora, which had been made about 1 mile northiwest of Lytle, on the Laredo road. This locality is in Atascosa County, about 22 miles southwest of San Antonio, on the Gillam land. The collection contains 35 species:

Ampelocissites lytlensis.

Anacardium kirni.

Anemia eocenica.

Anona ampla. eolignitica.

Apocynophyllum wilcoxense.

Artocarpoides kirni.

Artocarpus pungens.

Banisteria repandifolia. 
Celastrus taurinensis.

Cinnamomum postnewberryi.

Cucurbites scrobiculatus.

Dryophyllum tennesseense.

Engelhardtia ettingshauseni.

Euonymus splendens.

Ficus mississippiensis. occidentalis.

pseudopopulus.

schimperi. vaughani.

Gleditsiophyllum eocenicum.

Glyptostrobus europaeus.

Heisteria sapindifolia.

Laurus? caudata.

Lygodium kaulfussi.

Magnolia angustifolia. leei.

Nectandra sp.

Nyssa eolignitica.

Oreodaphne obtusifolia.

Palmocarpon butlerene.

Proteoides wilcoxensis.

Sabalites grayanus.

Terminalia eolignitica. hilgardiana.

In a locality about 7 miles northeast of Lexington, Lee County, Tex., Glenn Stewart collected specimens of Wilcox flora from the Carrizo sand. The following plants have been determined from this collection:

Cinnamomum sp.

Diospyros ef. D. miriflorianum.

Dryophyllum tennesseense.

Juglans schimperi.

From a collection made by Julia Gardner on the old Parmenter place, northeast of Mount Pleasant, Titus County, Tex., the following plants have been determined:

Leguminosites arachioides minor.

Liquidambar wilcoxianum.

Palmocarpon butlerense.

\section{SYSTEMATIC DESCRIPTIONS}

MORACEAE

Artocarpoides kirni Berry, n. sp.

Plate 24, figures 1-5

Leaves relatively large, but showing considerable variability in size. Elongate elliptical in outline, margins entire, sometimes markedly undulatory. Texture coriaceous. Length ranging from 15 to 20 centimeters. Maximum width ranging from 7.75 to 10 centimeters. Petiole missing. Midvein stout, prominent. Secondaries stout, prominent, irregularly spaced, camptodrome. Tertiaries thin, percurrent, oblique to the secondaries and nearly at right angles with the midvein. Areolation indistinct.

This form is characteristic as based on a considerable number of incomplete specimens that collectively show all the features of this interesting species. The species is rather close to the previously described Artocarpoides balli, ${ }^{4}$ from which it differs in lacking the ovate form and pointed tip, in the less prominent areolation and thinner tertiaries, and in the attitude of the tertiaries, which are transverse instead of oblique and at right angles to the midvein instead of to the secondaries. The secondaries in the new form are also less rezular in both spacing and arrangement and more ascending.

The venation is that claracteristic of Artocarpoides and is exceedingly like that of various Recent entire species of Artocarpus, as, for example, Artocarpus rigida Linné or Artocarpus integrifolia Linné. It is also much like the American tropical Tertiary and Recent genus Coussapoa to which it may really be related, although Coussapoa has never been certainly recognized outside of equatorial America.

This is the third species of Artocarpoides to be recognized in the Wilcox.

Occurrence: Near Lytle, Atascosa County, 'Tex.; collected by A. J. Kirn. Dezierzanowski farm, 2 miles northeast of Carpenter, Bexar County, Tex.; collected by Lewis W. MacNaughton.

\section{Artocarpus sp.}

Plate 20, figures 3 and 4

Ball ${ }^{5}$ in 1930 and again in 1931 expressed the cpinion that all the nominal species of Artocarpus in our late Cretaceous and early Eocene, as well as some extreme variants which he discovered in Texas, are varieties of a single botanical species, which he calls Artocarpus lessigniana (Lesquereux) Knowlton. I am quite prepared to admit that this contention mar be partly if not wholly true, but I do not think that Ball has proved this, and I doubt very much if it is possible of proof with the material that is now at the disposal of paleobotanists or is ever likely to be availsble. Meanwhile there are other, and as it seems to me, most important considerations to be kept in mind.

The whole trend of work in paleobotany (at least the work that I regard as good) has been in the direction of fine discriminations and away from the lumping of doubtful relatives under a single name unless the evidence was particularly strong and no violence was done to the reasonableness of both the geographic and geologic range. I thoroughly believe in the propriety of calling attention to the possibility or probability of botanical identity in forms that have been given different names, and that is why Ball has been able to quote opinions of mine in support of his conclusions. I do not, however, believe in going so far as formally to change the names and to quote the synonymy as if the matter were conclusively established, as it is in the minds of systematists who use the work. If all of the

\footnotetext{
1 Berry, E. W., Additions to the flora of the Wilcox group: U. S. Geol. Survey, Prof. Paper 131, p. 8, pl. 4, figs. 8-10; pl. 5, 1922.

${ }^{5}$ Ball, O. M., Bot. Gazette, vol. 90, pp. 312-325, figs. 1-16, 1930; Texas Agr. and Mech. Coll. Bull., 4th ser., vol. 2 , no. 5, p. 52 , pl. 37 , figs. $1-3$, pl. 38 , figs. 1-8, pl. 39 ,
} figs. 1, 2, 1931 . 
forms included by Ball in Artocarpus lessigniana are correctly identified, then we have a single species with the remarkable range from the Laramie and Vermejo to the Wilcox, or in terms of European chronology, from the Danian to the Ypresian stages - a range that extends through millions of years and includes quite different ecologic groups. It is exactly the sort of thing exemplified in Ettingshausen's studies of the Tertiary flora of New Zealand and Australia 50 years ago and responsible for the widespread opinion among geologists that fossil plants lack any precise stratigraphic value. This opinion has been formed, as I have pointed out in many connections, through no fault of the fossil plants.

Some of Ball's material from Bastrop County, Tex., passed through my hands, and I am figuring two of the more interesting specimens, from photographs made at the time in the Geological Survey laboratory, because they show more detail than those figured in the publications cited above.

Occurrence: Bastrop County, Tex.

\section{ANONACEAE}

Anona ampla Berry

Plate 24, figure 6

Anona ampla Berry, U. S. Geol. Surv. Prof. Paper 91, p. 217, pl. 39, fig. 1; pl. 40, fig. 1; pl. 41, fig. 3, 1916.

This species has been recorded from seven localities between west Tennessee and southwestern Texas. The size of the species has ranged from 17 to 22 centimeters in length and from about 8 to 8.5 centimeters in width. A basal half of an enormous leaf from a locality near Lytle, Atascosa County, Tex., is about 50 percent larger than any specimens hitherto encountered and suggests a total length of about 30 centimeters and a measured width of 12.5 centimeters.

Occurrence: Near Lytle, Atascosa County, Tex.

\section{LEGUMINOSAE}

Leguminosites violensis Berry, n. sp.

Plate 21, figure 9

This species is represented by a narrow, linear, rather flat pod with circular compressed seeds about a centimeter in diameter. Both ends are gone in the single specimen, which has a length of 9 centimeters without any signs of tapering. The width is about 1.5 centimeters.

More than 80 species of Leguminosae are recorded from the Wilcox, and the majority of these are based upon foliage. The pod here described very probably represents one of these species. Rather numerous genera among the three principal families of this alliance could be mentioned whose living representatives have pods like this fossil pod, for example, some Cassia, Leucaena, and Mimosa. In particular I have seen existing South American Cassia pods that are practically identical with this fossil, but such comparisons are regarded as relatively profitless and probably mirleading.

Occurrence: Viola, Graves County, Kentuck'

\section{MALPIGHIACEAE \\ Banisteria repandifolia Berry \\ Plate 21, figures 1-5}

Banisteria repandifolia Berry, U. S. Geol. Surv. Prof. Paper 91 , p. 256, pl. 56, figs. $3,4,1916$.

It is always desirable in studying fossil leaves, and indeed all types of fossils, to have a large amount of material in order that the student may get some idea of the extent of variation within the species. There is an unusually large series of leaves of this species in the collection from Viola, Ky., which, in addition to showing a considerable range in the size of the leaves, indicates a rather constant short stout petiole, a considerable narrowing from the normally rounded base, wlich last is sometimes quite inequilateral, and great variability in the extent to which the tip is developed into a typical apiculate "dripping point."

Occurrence: Viola, Graves County, Ky.

\section{ANACARDIACEAE}

\section{Anacardium kirni Berry}

Plate 23, figures 8, 9

Anacardium kirni Berry, Wash. Acad. Sci. Jour., vol. 19, p. 38, figs. 1, 2, 1929.

Seeds unsymmetrically reniform in side viev', somewhat compressed, broadly rounded distad, narrowed and pointed proximad, somewhat bean-shaped but less symmetrical than any legume known to me. Length, 17 millimeters; maximum width, 12 millimeters; maximum thickness, 9 millimeters; decreasing proximad. Surface smooth. Sinus about 4 millimeters al ove the base. No trace of the seed coat.

As this species is based upon a single specimen, it cannot be described properly, nor can the possible limits of variation be determined.

The genus Anacardium contains 8 or 10 sfecies of shrubs and trees in the existing flora. Outside of cultivation these are confined to the American wet tropics. The leaves are rather characteristic and the fruits are exceedingly so.

Saporta long ago proposed a form genus, Anacardites, for fossil leaves supposed to belong to the family Anacardiaceae, but which could not be referred with certainty to any of the existing genera of the family. About a score of species have been referred to Anacardites, but these, with the single exception to ke noted presently, resemble those of genera such as Mangifera, Anaphremium, and Spondias, and are not like the leaves of Anacardium itself.

The exception mentioned is Anacardites balli Berry ${ }^{6}$

6 Berry, E. W., The middle and upper Eocene floras of southeastern North Amer ica: U. S. Geol. Surv, Prof, Paper 02, p. 177, pl. 62, fig. 7, 1924. 
from the Jackson Eocene (Fayette sandstone) in Brazos and Grimes Counties, Tex. Although it cannot be demonstrated conclusively, I believe that this form is closely related to Anacardium, and this identification is rendered more probable by the discovery of the seed described above. These nuts, although they greatly resemble the fruits of the leguminous genus Dalbergia, have been found in Colombia, ${ }^{7}$ Ecuador, ${ }^{8}$ and Peru ${ }^{9}$ and the very abundant material from the Oligocene of Peru has made it possible to demonstrate the inner secretory layer and the outer seed coat, so that there is no doubt of their identity. It adds an interesting and tropical element to the Wilcox flora.

Occurrence: Near Lytle, Atascosa County, Tex.

\section{SAPINDACEAE}

Carpolithus pseudimaformis Berry, n. sp.

Plate 23, figure 5

An excellent specimen of a fruit that appears to be related to the fruits of several existing genera of Sapindaceae is contained in the collection from Wickliffe, Ballard County, Ky. It is bicarpellary, papillate, somewhat compressed, indehiscent, about 1 centimeter high and 1.75 centimeters wide, and the central axis is terminated by a small persistent sytle. It shows a superficial resembalance to some members of the Rutaceae, for example, Fagara piperitum De Candolle, but is larger and lacks the two persistent styles of the mostly disjunct capsules of this family.

The general resemblances are to certain genera of the Sapindacene, such as the African genus Aporrhiza Radlkofer or more particularly the South American genus Pseudima Radlkofer. The resemblance to the latter has suggested the specific name. The genus is monotypic in the existing flora and is based on a shrub or tree of northern South America (the Guianas and northern Brazil).

Occurrence: Wickliffe, Ballard County, Ky.

\section{CELASTRACEAE}

Celastrus violensis Berry, n. sp.

Plate 23, figure 19

Leaves small, ovate in outline with a stout petiole, a broad ultimately decurrent base, and acute tip. Margin with serrulations widely spaced by interspersed shallow-curved sinuses. Length, about 2.5 centimeters; maximum width, about 1.7 centimeters. Midvein relatively stout. Secondaries, about 5 pairs, diverging from the midvein at angles of about $45^{\circ}$, irregularly spaced, camptodrome. This characteristic little leaf resembles a group of existing South African species such as Celastrus

\footnotetext{
7 Berry, E. W., Am. Jour. Sci., 5th ser., vol, 8, p. 124, figs. 1-8, 1924.

8 Berry, E. W., Jour. Paleontology, vol. 3, p. 301, fig. 3, 1929.

- Berry, E. W., Johns Hopkins Univ. Studies in Geology, No. 10, p. 159, pl. 2, figs. $1-16,1929$.
}

buxifolius, C. leptopus, C. nemorosus, C. rupestris, C. acuminatus, and C. cassinoides and also Putterlickia pyracantha from that same general region. This resemblance is interesting, but is not believed to be of any significance. The present contribution adds two speries to this genus already represented in the Wilcox by six species.

Occurrence: Viola, Graves County, Ky.

\section{Celastrus robertsi Berry, n. sp.}

Plate 23, figure 20

Leaves of medium size, ovate in outline, with a broadly rounded base and acute tip. Length, about 7 centimeters; maximum width, about 5 centimeters. Midvein stout, prominent. Secondaries stout, opposite or subopposite, 6 or 7 pairs, diverging from the midvein at angles of about $45^{\circ}$, rather straight, subparallel, camptodrome. Tertiaries percurrent between the secondaries, camptodrome from the outside of the besal secondaries extending into the fairly prominent serrate teeth of the margin as short curved branches as shcwn in the accompanying illustration.

This species is similar in form, size, and other features to Celastrus ferrugineus Ward, ${ }^{10}$ of the Fort Union formation of Montana, but differs in minor particulars, chiefly in its fewer secondaries.

Associated with this small and medium-sized Celastrus is a much larger species that has been recorded from several localities in the Wilcox and has been called Celastrus taurinensis Ward. A specimen from Viola, Ky., is figured on plate 23, figure 12, of the presont contribution. Certain unevaluated differences between the Wilcox material and the Fort Union type are obvious, chiefly the finer marginal teeth of the former, and the student may well doubt the validity of the identification. Recently Sanborn ${ }^{11}$ has referred this species of Ward to Aralia.

Occurrence: Viola, Graves County, Ky

\section{OLACACEAE}

\section{Heisteria sapindifolia (Hollick) Berry}

Heisteria sapindifolia (Hollick) Berry, Torreya, vol. 38, p. 6, 1938.

Apocynophyllum sapindifolium Hollick, in Harris and Veatcl. A preliminary report on the geology of Louisiana, p. 288, pl. 46, fig. 3, 1899.

Berry, U. S. Geol. Survey Prof. Paper 91, p. 344, pl. 102, fig. 1 ; pl. 108, fig. 5, 1916; Prof. Paper 156, p. 129, pl. 19, figs. 13, 14; pl. 44, fig. 19, 1930.

Calycites milanensis Berry, U. S. Geol. Survey Prof. Paper 156, p. 142, pl. 49, figs. $6-8,1930$.

It has recently been shown that the concrescent $\mathrm{c}^{-1 \mathrm{li}-}$ ces described as a species of Calycites in 1930 are those of the genus Heisteria of the family Olacaceae, and among

10 Ward, L. F., Types of the Laramie flora: T. S. Geol. Surv. Bull. 37, p. 78, pl. 34, figs. $1-4,1887$.

${ }^{11}$ Sanborn, E. I., Carnegie Inst. Pub. 465, p. 27, 1935 
SHORTER CONTRIBUTIONS TO GENERAL GEOLOGY, 1938-40

the fossil leaves associated with these calices the only ones that show features of identity with the leaves of existing species of Heisteria are those long known and widely distributed in the Wilcox under the name of Apocynophyllum sapindifolium. It is believed that the available evidence warrants uniting these leaves and calices, which are recorded from 28 different localities along both the eastern and western shores of the Wilcox embayment, under a single specific name.

The disconnected modern range of the 20 to 25 genera of the Olacaceae strongly suggests that the family has had an extended Tertiary history, although paleobotanists have usually ignored it, and but two species have been recorded, representing the genera Olax Linné and Erythropalum Blume. The identification of these was based on carpologic material, and both were described by Reid and Chandler from the London clay. ${ }^{12}$ These species, like the American representatives, are of lower Eocene age and show that thus early in the Tertiary the family was present on two continents.

The genus Heisteria, to which the present Wilcox species is referred, contains over a score of existing species of trees almost wholly confined to tropical Central and South America but sparingly represented in tropical West Africa. The fossil calices are closest to those of various Central American species, such as $H$. acuminata and $H$. costaricensis, and the leaves resemble those of a large number of existing species in the genus that have minimum-sized leaves.

As conceived by the writer, who follows Hutchinson's recent arrangement, the Olacales should be placed between the Celastrales and Rhamnales and should be considered to be derived from the Celastrales, from which the Rhamnales, also, are believed to be derived.

\section{VITACEAE}

\section{Ampelocissites lytlensis Berry}

Plate 23, figure 1-3

Ampelocissites lytlensis Berry, Wash. Acad. Sci. Jour., vol. 19, p. 39, fig. 1, 1929; Kirn and Parks, Texas Acad., Trans., vol. 19, p. 14, fig. 1, 1936 .

Seed relatively small, ovate in profile, broadly rounded distad, bluntly and obliquely pointed proximad, with an inflated crustaceous coat. Somewhat flattened in the region of the furrows, which result from the conduplicate habit of the embryo. There is a fairly sharp keel between these furrows, and the furrows themselves diverge somewhat distad and extend for slightly more than half the length of the seed. On the side opposite the furrows there is a well-marked central elongated depression containing the hilum. This depression is continued upward to the apex as a shallow furrow and downward as a narrower raphe groove to the base at the chalazal pointed end. The surface of the seed is not

14 Reid, F. M., and Chandler, M. E. J., The London clay flora, 561 pp., 33 pls., 17 figs., British Mus. (Nat. History), 1933. evenly rounded but is thrown into irregular obliquely transverse ridges, as in Ampelocissus and Tetrastigma. Length, 4 millimeters; maximum width, 3.5 millimeters; maximum thickness, 1.75 millimeters.

This seed differs from those of Vitis in the shorter and less prominent raphe, in the less prominent furrows, and in the transverse ornamentation, which is hinted at in the southern ancestor of Vitis rotundifolia Michaux. The fossil lacks also the cordate apex and the stipitate base of Titis. It resembles the seeds of Ampolocissus in all these features, and $I$ therefore regard it as intermediate between Ampelocissus and Titis and propose for it the generic term Ampelocissites.

The existing genus Ampelocissus of Planchon contains about 60 species found in the tropics of both hemispheres. It is largely Old World (Asia and Africa) in its habitat but is represented also in the Antilles and Central America. In the western tropics, Jowever, it is largely replaced by numerous species of the prolific tropical genus Cissus. The fact that Ampelocissus occurs on three continents is in itself an indication of its antiquity, and a characteristic seed indistinguishable from those of the existing species has been described by the writer from the Eogene of northwestern Peru. ${ }^{13}$

The genus ritis, with about 40 existing srocies, is confined to the northern hemisphere, although it thrives in cultivation in antipodean regions in both the equatorial and temperate zones. The genu? Tetrastigma contains about 40 existing species native to tropical and subtropical Asia and Malaysia eastward as far as New Guinea. Several characteristic fossil species of seeds have been described from the London clay (Ypresian) ${ }^{14}$ and from the upper Eocene of the Hampshire basin, ${ }^{15}$ in England, and also from the brown coal of Germany.16 Kirn and Parrss have referred to this species certain leaves which are associated with the seeds at the type locality. These leaves are very similar to those from the Grenada formation of western Tennessee which I have described as Cissites asymmetricus. ${ }^{17}$

Occurrence: Near Lytle, Atascosa County, ...ex.

\section{BOMBACACEAE}

\section{Bombacites eocenicus Berry}

Plate 22, figures 1-7

Bombacites eocenicus Berry, U. S. Geol. Survey Prof. Faper 156, p. 106, pl. 36, fig. 8, 1930.

The genus Bombacites was proposed in 1916 with Bombacites formosus, from the lower Eocene, as the

${ }_{13}$ Berry, E. W., Johns Hopkins Univ. Studies in Geology, No. 10, p. 161, pl. 3, figs. 1, 1a, 1929.

14 Reid, E. M., and Chandler, M. E. J., The London clay flora, p. 383, pl. 19, figs. 6-9, British Mus. (Nat. History), 1933.

${ }^{15}$ Reid, E. M., and Chandler, M. E. J., The upper Eocene flora of Handle, Hants: Palaeont. Soc. Pub., p. 32, pl. 5, fig. 3a-c, 1925.

16 Kirchheimer, F., Braunkohle, 36. Jahrg., Heft 50, p. 118, fig. 18, 1937.

17 Berry, E. W., U. S. Geol. Survey Prof. Paper 156, p. 103, pl. 35, figs. 1-5, 1930. 
type. One other species was described from the lower Eocene (Wilcox), and some years later a third species was described ${ }^{18}$ from the upper Eocene (Jackson). The last may be regarded, with some justice, as not conclusively identified. The present species was described from the Wilcox Eocene of Calloway County, Ky., and its identification was based upon a very limited amount of material. In the more recently collected material from Viola, Graves County, which is between 25 and 30 miles northwest of the type locality, the leaflets of this species are very abundant (about 30 specimens) and in an excellent state of preservation, although invarably detached. This abundance of specimens and their well-preserved condition affords one an opportunity to get an idea of the range in variation of the species not usually vouchsafed to students of foliar remains. That all appertain to a single botanical species, despite the rather wide limits of variation, is demonstrated by their close association, their identity in facies, texture, and areolation. A few of the specimens are illustrated, but it is obviously impossible to figure all of them.

They range in size from lanceolate forms measuring 5.5 by 1.7 centimeters or slightly ovate forms measuring 4 by 2 centimeters though broadly lanceolate, oblanceolate, or subelliptical forms, the largest being as much as 12 centimeters in length. The base is narrowly to widely cuneate, sometimes slightly acuminate. The apex varies from rounded to acute and is frequently acuminate. The petiolule is always very short and stout, and the midvein is invariably stout and prominent. The secondaries are numerous, the angle of divergence becoming less with the decrease in relative width of the leaflets. The areolation and texture are rather uniform throughout. The degree of prominence and the character of the marginal teeth vary considerably, ranging from straight serrate to dentate or even crenate. The teeth may be very minute and absent proximad, or present throughout the extent of the margins, or prominent.

The differences between the present species and the other two Wilcox species were pointed out in the original discussion and hold good for the variant material subsequently collected.

Individual leaves may be picked out which show a superficial resemblance to Bombacites formosus, but careful comparison at once discloses the differences already pointed out. The species is a fine one, and the present series is a striking illustration of the hazards of describing a species from a single specimen, since any one of the variants - if the only one known, might be taken as the type of a distinct species.

Occurrence: Bell City Pottery pit and 100 yards east of it, Galloway County, Ky. (pl. 22, fig. 6) ; Viola, Graves County, Ky. (pl. 22, figs. 1-5, 7).

${ }^{13}$ Berry, E. W., U. S. Geol. Survey Prof. Paper 92, p. 180, pl. 31, fig. 14; pl. 35, figs. $1,5,1924$.

$264406-40-2$

\section{COMBRETACEAE}

Bucida eocenica Berry, n. sp.

Plate 21, figure 6

Leaves obovate, subsessile, frequently somewhat inequilateral, rounded at the apex or broadly angled, narrowly cuneate to slightly decurrent at the base. Margins entire. Texture coriaceous but not excessively thickened. Length, about 6 centimeters. Maximum width, at or above the middle, about 2.5 centimeters. Midvein unusually stout and prominent, expanding at the base. Secondaries, about 6 pairs, stout, not very regularly spaced; they diverge from the midvein at an angle of about 35 degrees, ascending in more or less subparallel curves, eventually camptodrome. Tertiaries immersed in the leaf substance.

The present form is entirely unlike anything previously known from the Wilcox, but it is as yet unfortunately represented only by a small amount of material. It agrees remarkably in size, outline, and other features with the leaves of the existing black olive, Bucida buceras Linné, a shrub or tree of shores and brackish marshes in equatorial America, where it ranges from southern Florida through the Antilles to Central America and northern South America. The genus is monotypic in the existing flora.

There are genera in other families which contain species that resemble the present fossil more or less closely, for example, Eugenia of the Myrtaceae, Bumelia of the Sapotaceae, and Citharexylon of the Verbenaceae; but, although there may be some skepticism as to the fossil representing Bucida exactly, I believe that it represents, if not the modern genus, then a closely related extinct one and that it belongs in the family Combretacene. The oriental red mangrove, Lumnitzera, often has very similar leaves, but in general its leaves are more coriaceous and differ in other details, and there is slight probability that it was ever represented in the Mississippi embayment.

Occurrence: Wickliffe, Ballard County, Ky.

\section{Combretum wilcoxense Berry \\ Plate 23, figure 22}

Combretum wilcoxense Berry, U. S. Geol. Surv. Prof. Paper 91, p. 321 , pl. 89 , figs. $1,2,1916$.

An incomplete but perfectly characteristic leaf of this species is illustrated here because it shows the extent to which, after falling in the water, it has been galleried by Cecidomyia larvae.

Occurrence: Viola, Graves County, Ky.

\section{ARALIACEAE \\ Schefflera? elliptica Berry \\ Plate 23, figure 10}

Schefflera? elliptica Berry, U. S. Geol. Survey Prof. Paper 156, p. 124, pl. 41, fig. 10, 1930.

The single small leaf that is here figured undoubtedly belongs to the same species as the specimens from the 
Holly Springs sand of Henry County, Tenn., which were described under the above name and which were rather tentatively referred to the genus Schefflera. The present specimen is somewhat shorter and more rounded than the type, but the tip is not complete, which makes it appear more rounded than it really is. In size, texture, and venation and in character of the petiolule this leaf is clearly identical with the Tennessee type.

Occurrence: Wickliffe, Ballard County, Ky.

MYRSINACEAE

Icacorea prepaniculata Berry

Plate 21, figure 7

Icacorea prepaniculata Berry, U. S. Geol. Survey Prof. Paper 91, p. 332, pl. 107, fig. 5, 1916; Am. Jour. Sci., vol. 21, pp. 301-303, fig. 1, 1931.

This species is of wide geographic extent in the later Wilcox, but it is rather uncommon, having been found heretofore only at three localities in western Tennessee and one in Texas, in Smith County. The specimen figured shows unmistakable evidence of the ravages of leaf-cutting bees.

Occurrence: Viola, Graves County, Ky.

EBENACEAE

Diospyros cf. D. miriflorianum Berry

Plate 23, figure 4

This identification is based upon the single specimen figured, which is compared to Diospyros miriflorianum Berry from the sandstone (of Jackson age) formerly designated Fayette sandstone, in Webb County, Tex. ${ }^{19}$ The present specimen is probably distinct from this Texas form, but it is too incomplete for accurate distinction or characterization. It represents a rather large five-parted concrescent calyx with five narrow parallel-sided lobes surrounding the characteristic collared disk. The disk is about 6 millimeters in diameter, and the whole calyx from 3 to 3.5 centimeters. This fossil agrees with Diospyros miriflorianum in being five-lobed, but differs in the smaller disk and parallelmargined lobes. There is a striking resemblance to the five-lobed concrescent calyx of Heisteria guianensis Engler of the family Olacaceae, but after the most careful comparisons I have decided in favor of a relationship to Diospyros.

Occurrence: 7 miles northeast of Lexington, Lee County, Tex.

\section{CUCURBITACEAE}

Cucurbites scrobiculatus Berry, n. sp.

Plate 23, figures 6, 7

Seeds relatively large, compressed lenticular, obovate in profile, asymmetrically rounded distad, truncated proximad, with a slight smooth border about 0.5 millimeters in diameter widening toward the hilum. Surface prominently ornamented by irregularly rounded pits about a millimeter in diameter. Length, 2.1 centimeters; maximum width, 1.3 centimeters; maximum thickness, about 3.5 millimeters. Texture coriaceous.

Occurrence: Near Lytle, Atascosa County, Tex.

19 Berry, E. W., U. S. Geol. Surv. Prof. Paper 92, p. 195, pl. 40, fig. 5; pl. 43, fig. 5 , 1924. 
PLATES 20-24 
PLATE 20

FIGURE 1. Dryophyllum puryearense Berry. Wickliffe, Ky.

2. Magnolia leei Knowlton. Wickliffe, Ky.

3, 4. Artocarpus sp. Bastrop County, Tex.

92 


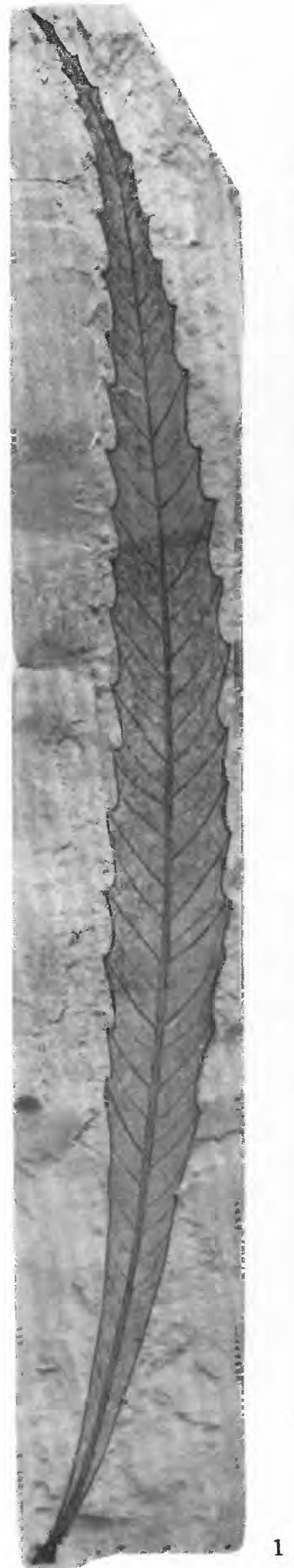

$264406-41-3$
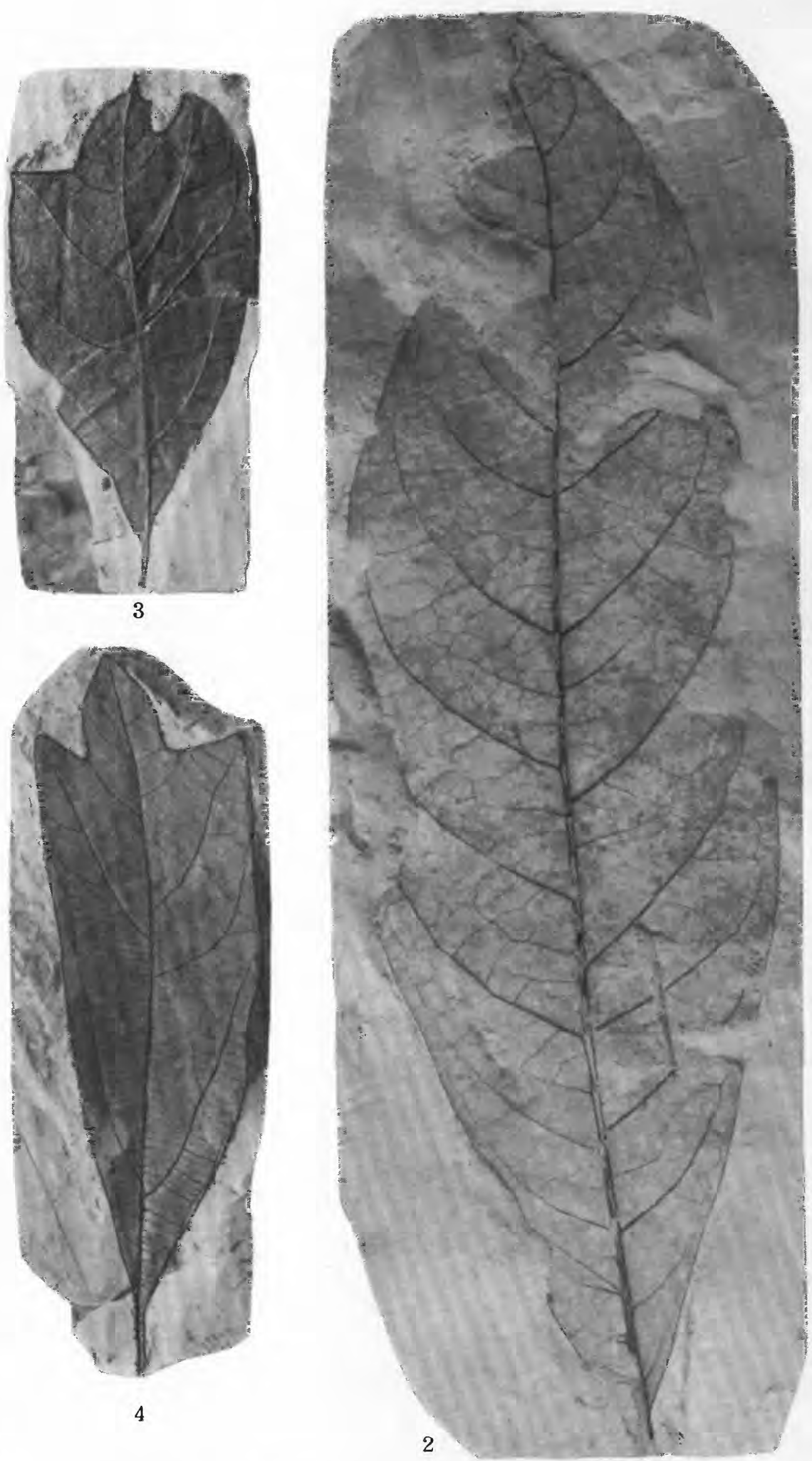

WILCOX FLORA. 

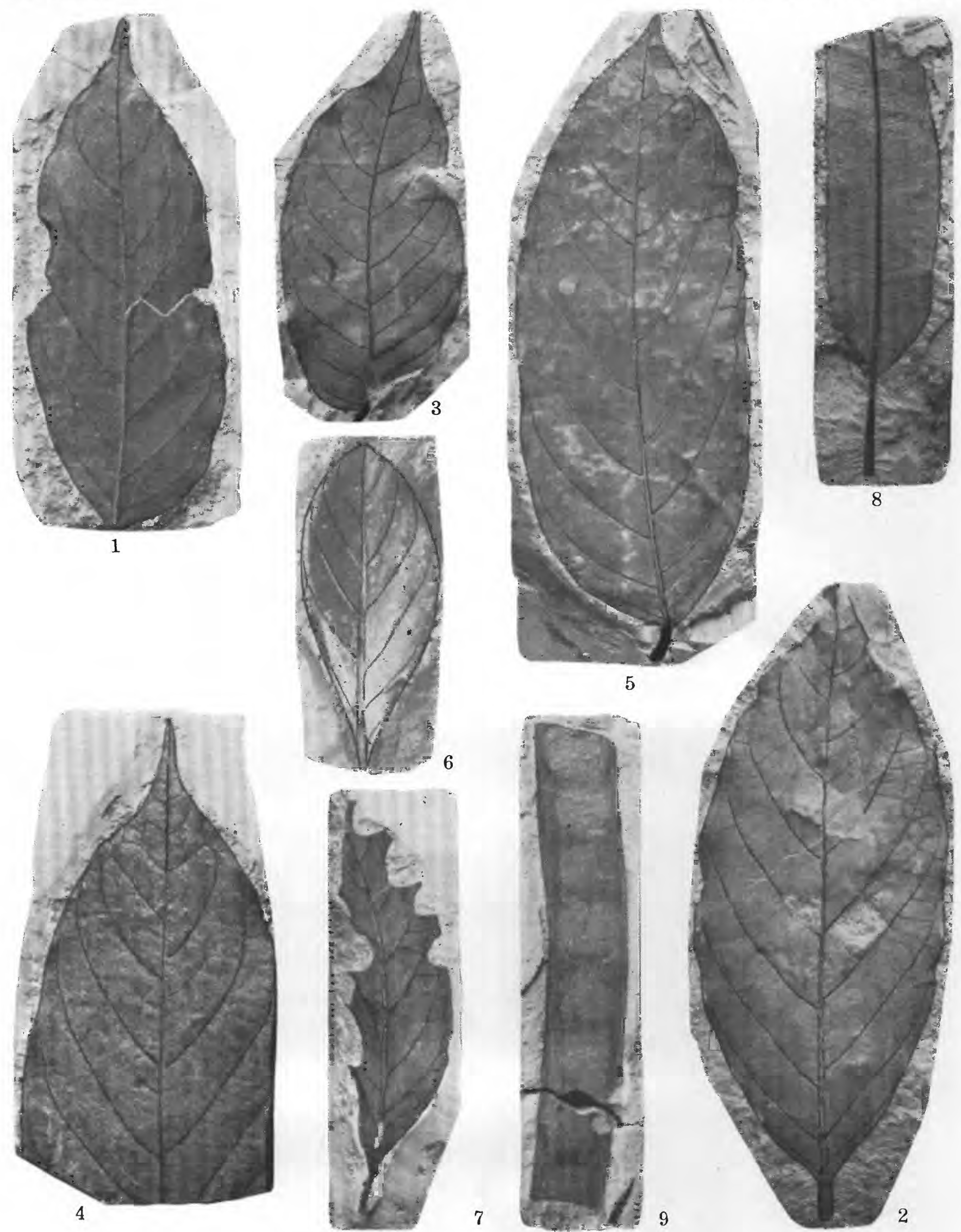

WILCOX FLORA. 
PLATE 21

FigURes 1-5. Banisteria repandifolia Berry. Viola, Ky.

6. Bucida eocenica Berry, n. sp. Wickliffe, Ky.

7. Leaf of Icacorea prepaniculata Berry, cut by insects. Viola, Ky.

8. Ficus myrtifolia Berry. Viola, $\mathrm{Ky}$.

9. Leguminosites violensis Berry, $\mathrm{n}$. sp. Viola, Ky. 
PLATE 22

Figures 1-7. Bombacites eocenicus Berry. 1-5, 7, Viola, Ky.; 6, Bell City pottery pit, Ky. (From Geol. Survey Prof. Paper 156, pl. 36, fig. 8, 1930.) 
GEOLOGICAL SURVEY
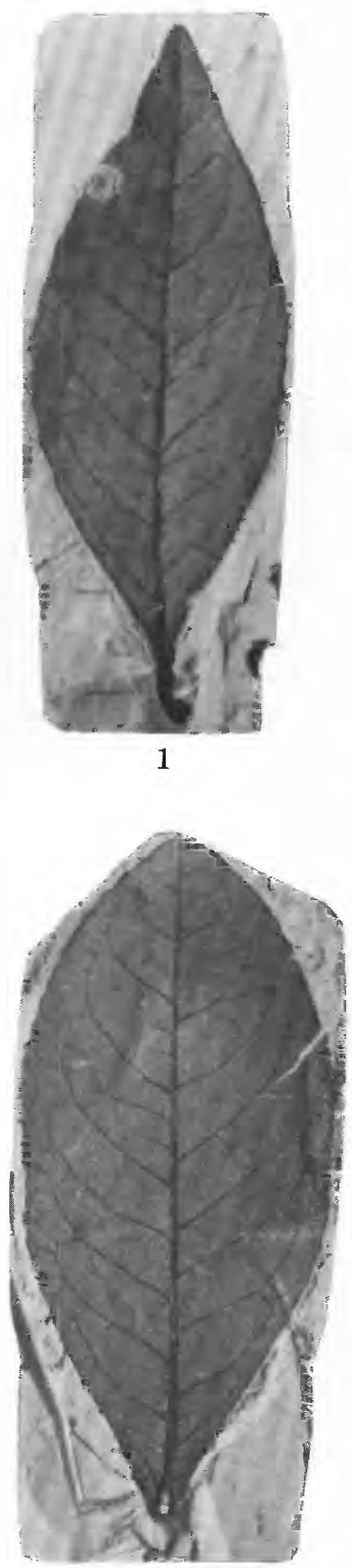

5
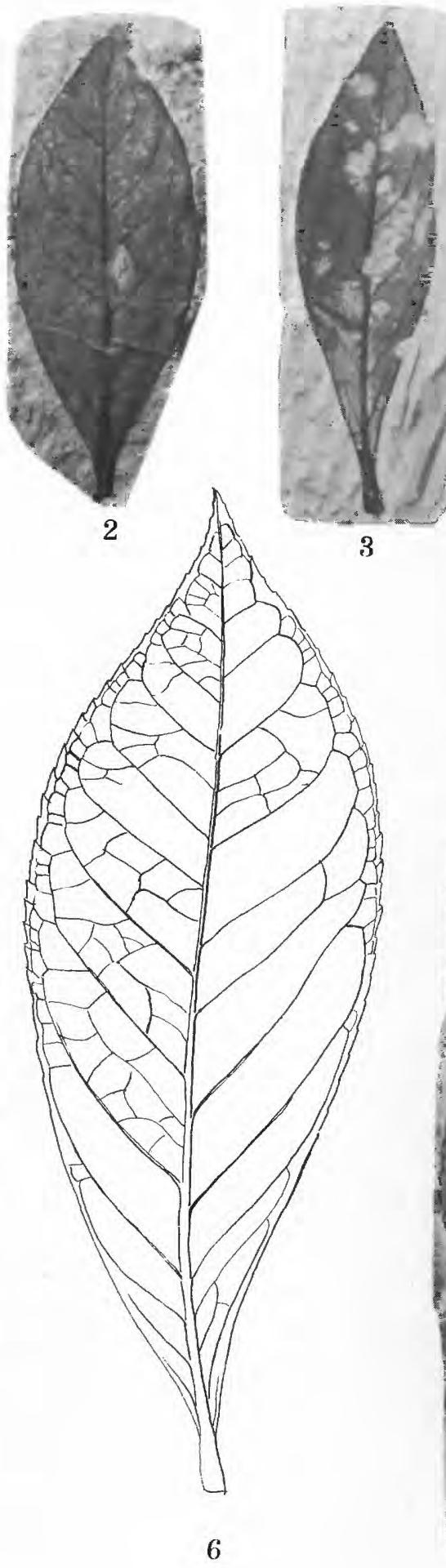

WILCOX FLORA.
PROFESSIONAL PAPER 193 PLATE 22
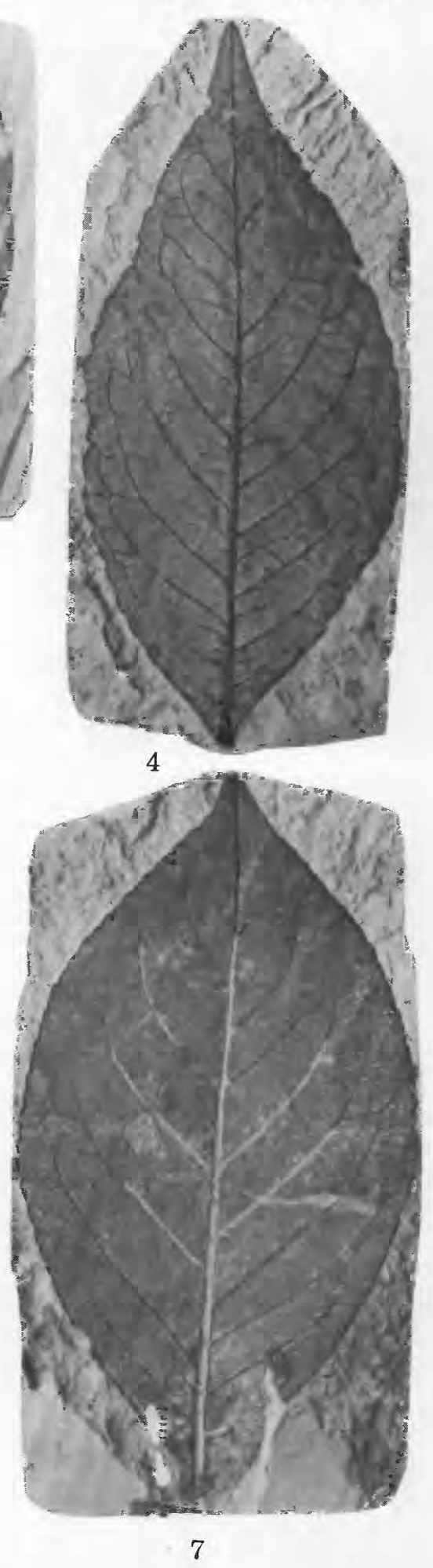

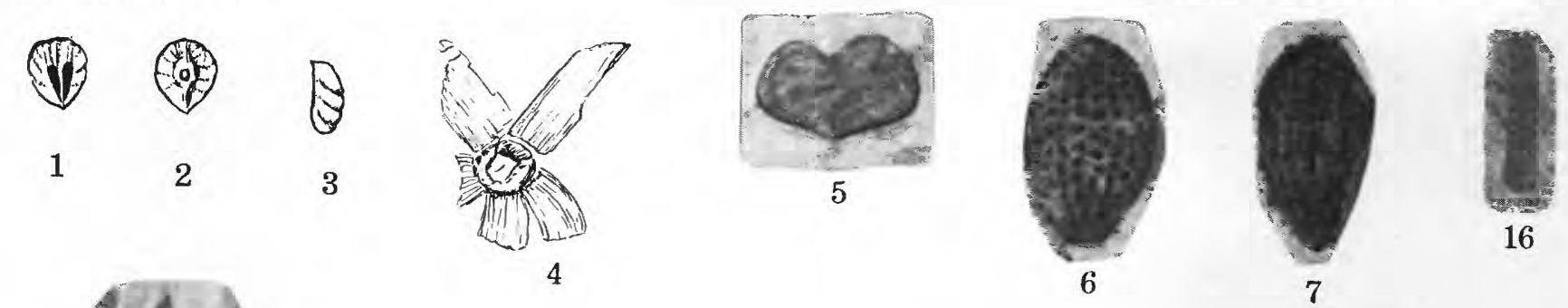

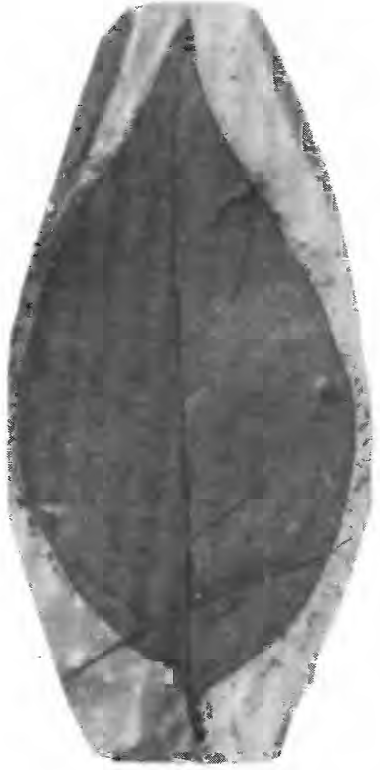

21

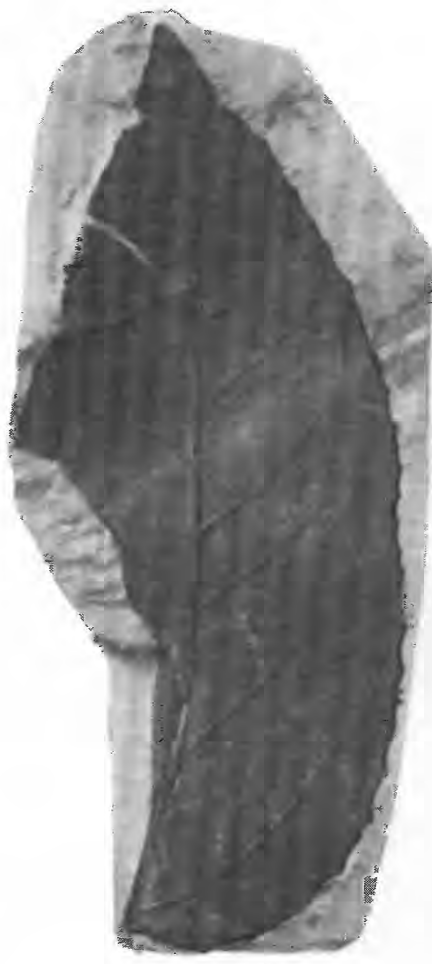

12

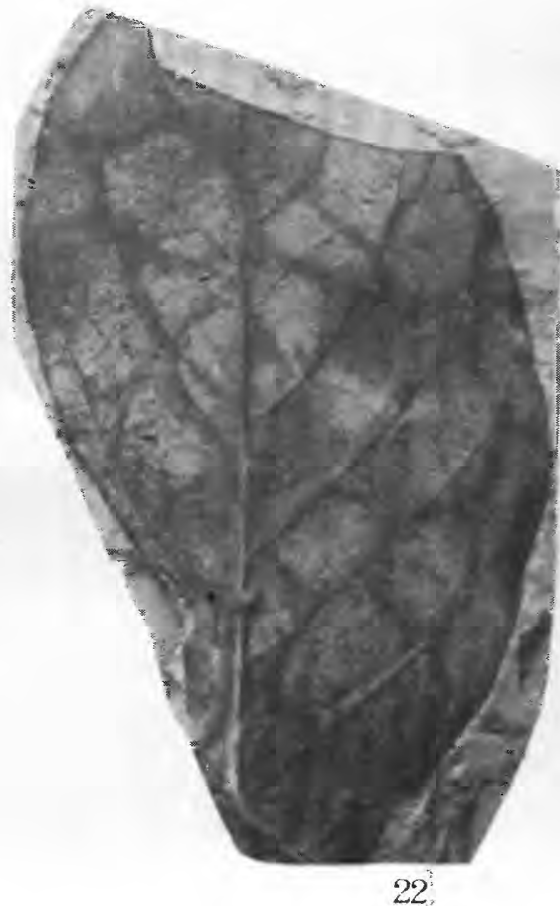

WILCOX FLORA.
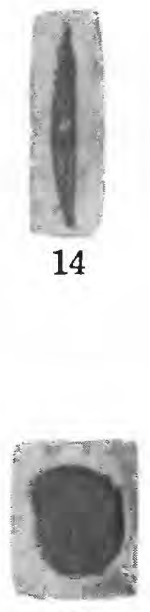

17

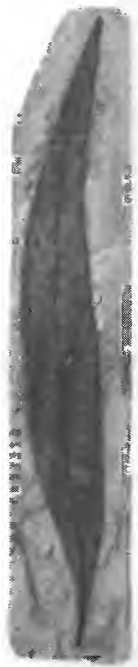

15
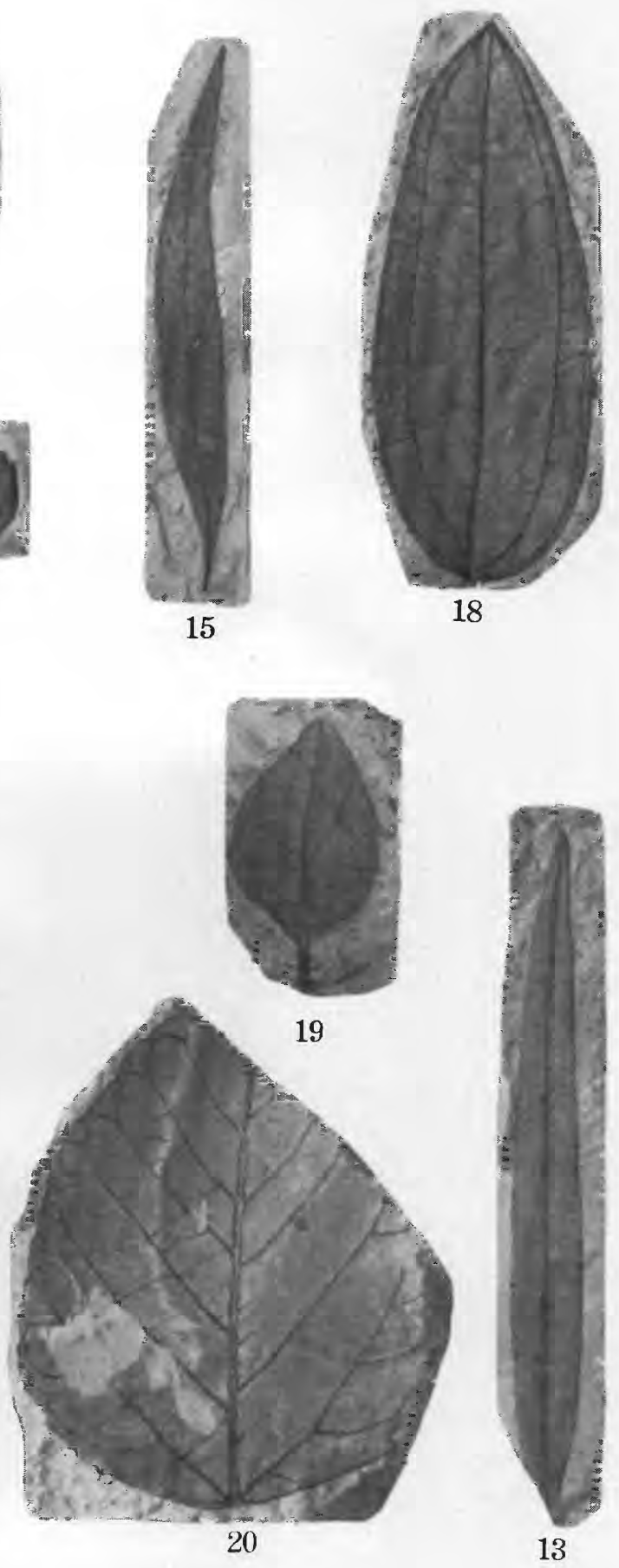


\section{PLATE 23}

Figures 1-3. Ampelocissites lytlensis Berry, dorsal, ventral, and side views. x 2. Near Lytle, Ataseosa County,Tex.

4. Diospyros cf. D. miriflorianum Berry. 7 miles norteast of Lexington, Lee County, Tex.

5. Carpolithus pseudimaformis Berry, n. sp. Wickliffe, Ky.

6, 7. Cucurbites scrobiculatus Berry, n. sp. Slightly enlarged. Near Lytle, Atascosa County, Tex.

8, 9. Anacardium kirni Berry. Near Lytle, Atascosa County, Tex.

10. Schefflera elliptica Berry. Wickliffe, Ky.

11. Anona robertsi Berry. Seed. Wickliffe, Ky.

12. Celastrus taurinensis Ward. Viola, Ky.

13-15. Sapindus linearifolius Berry. Viola, Ky,

16. Caddis case. Viola, $\mathrm{Ky}$.

17. Fish scale. Mandy, Tenn.

18. Melastomites verus (Berry) Berry. Viola, Ky.

19. Celastrus violensis Berry, n. sp. Viola, Ky.

20. Celastrus robertsi Berry, n. sp. Viola, Ky.

21. Cassia puryearensis Berry. Wickliffe, Ky.

22. Leaf of Combretum wilcoxense Berry, with Cecidomyia galleries. Viola, Ky. 


\section{PLATE 24}

[All figures three-fourths natural size]

Frgures 1-5. Artocarpoides kirni Berry, n. sp. Near Lytle, Atascosa County, Tex. 6. Anona ampla Berry. Near Lytle, Atascosa County, Tex.

96 

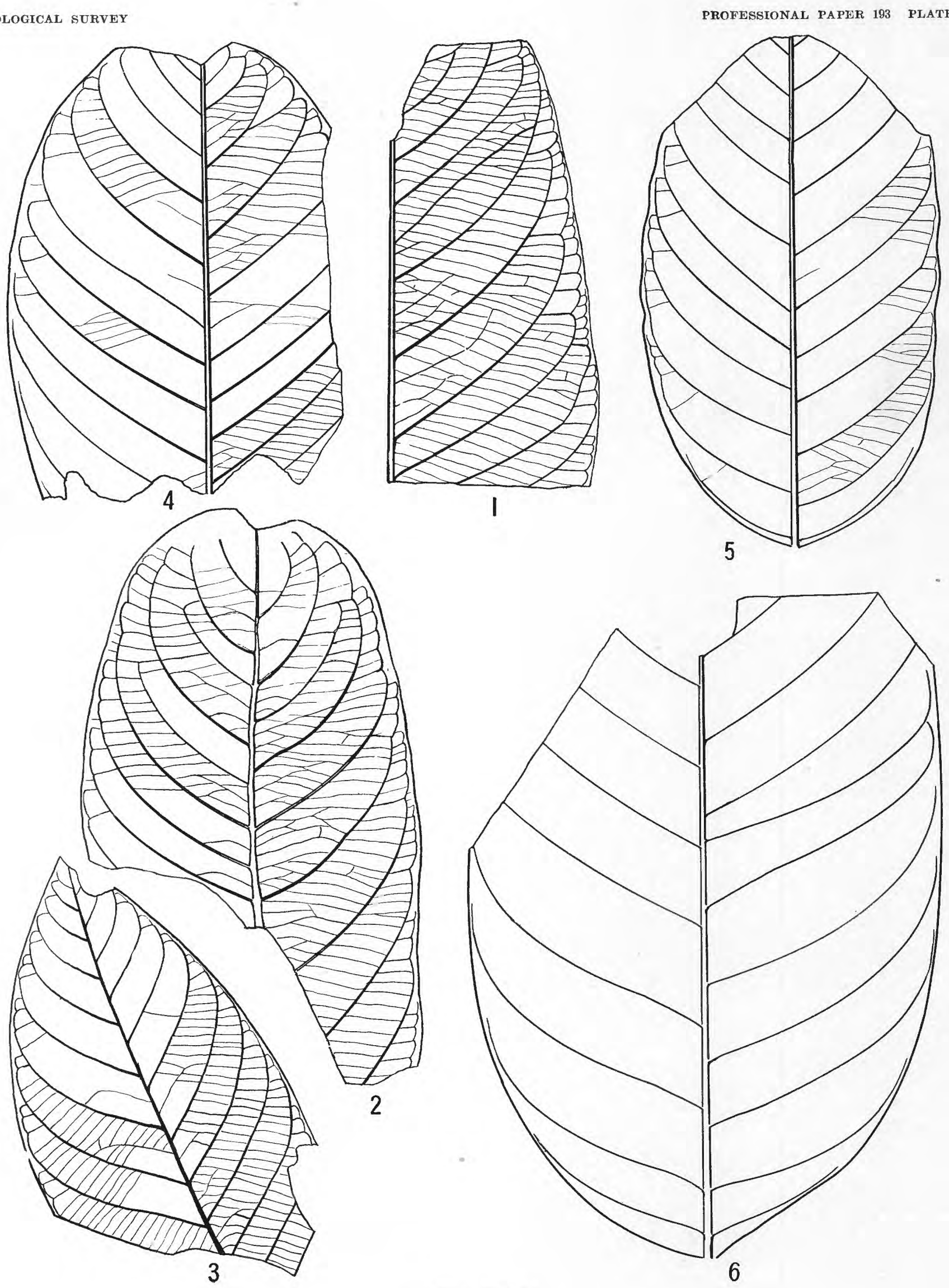

WILCOX FLORA. 


\section{N D E X}

A

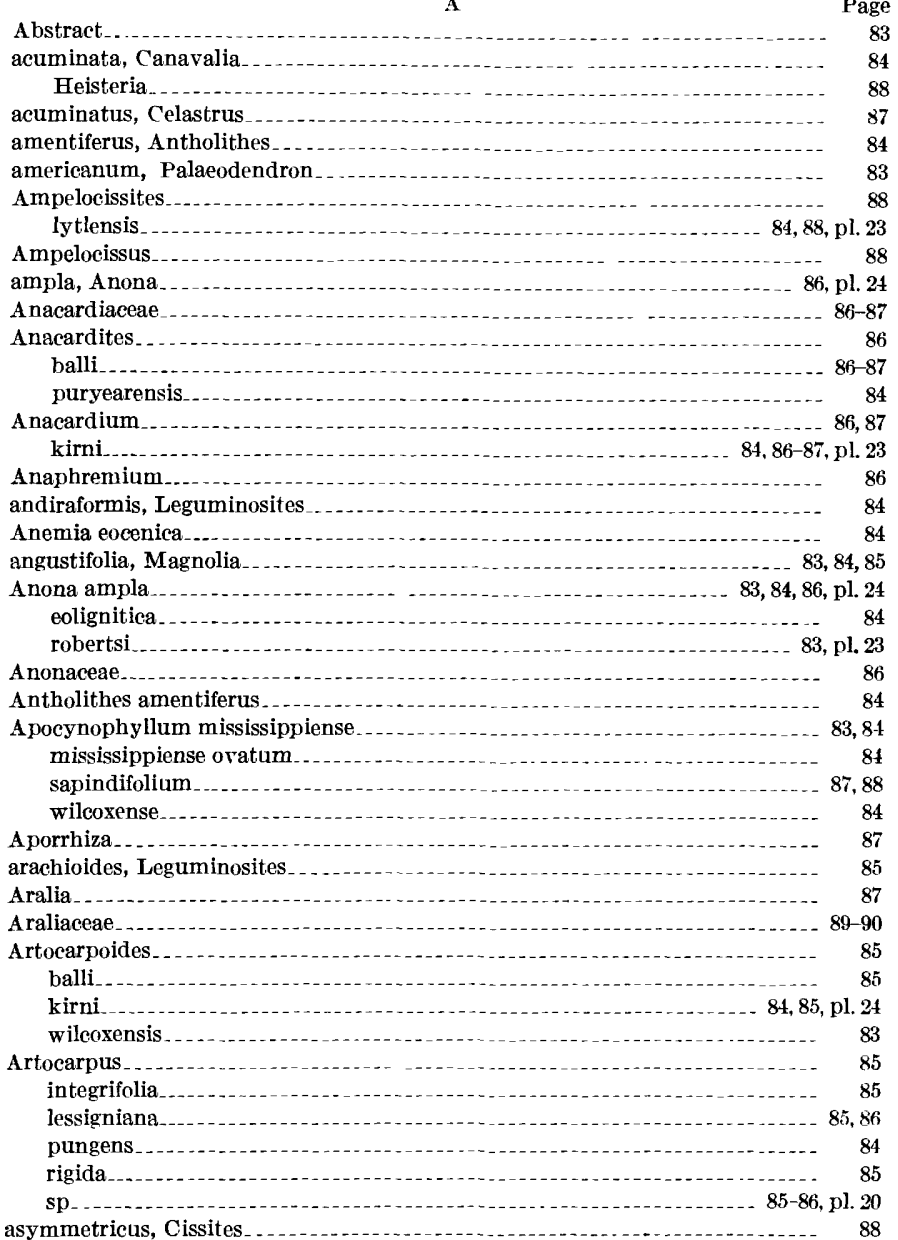

balli, Anacardites Artocarpoides.

Banisteria pseudolaurifolia repandifolia..

Banksia saffordi

bentonensis, Myrcia

Boaz, Ky., list of species from.

Bombacaceae

Bombacites

eocenicus

formosus.

cf. B. catha

buceras, Bucida

Bucida buceras

eocenica

Bumelia......

urseraformis, Carpolithus

butlerense, Palmocarpon

buxifolius, Celastrus

O

Calyeites

milanensis.

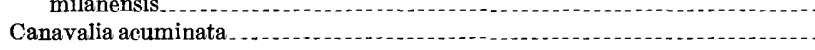
eocenica
Page

Capparis eocenica $\ldots \ldots \ldots$.

Carapa eolignitica

Carpolithus burseraformis _. _. 83

fagaraformis . . .

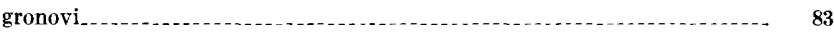

pseudimaformis . . . .

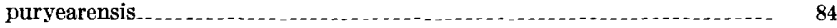

Carrizo sand, flora from . . .

Cassia emarginata

fayettensis

glenni . .

glenni major

puryearensis

cassinoides, Celastrus

caudata. Laurus . .

Cecidomyia . . .

Cedrela mississippiensis

odoratifolia

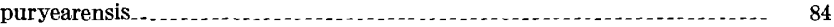

Celastraceae

$\begin{array}{lll}\text { Celastrocarpus eocenicus... } & 83 \\ \text { Celastrus... }\end{array}$

Celastrus_._.

acuminatus

$\begin{array}{lll}\text { buxifolius } & 87 \\ \text { cassinoides } & 87\end{array}$

$\begin{array}{lll}\text { cassinoides } & 87 \\ \text { ferrugineus. } & 87\end{array}$

leptopus 87

minor

nemorosus

robertsi

rupestris _........

taurinensis . . . . . . . . . 23

violensis . . . . . .

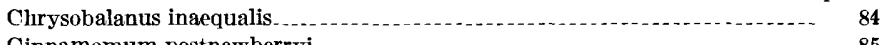

Cinnamomum postnewberryi

sp

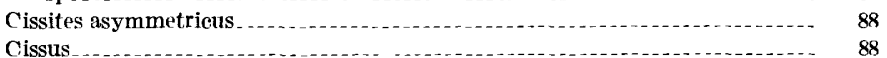

$\begin{array}{lll}\text { Cissus } & 88 \\ \text { Citharexylon } & 89\end{array}$

Coccolohis eolignitica

Combretaceae _...

Combretum wilcoxense

costaricensis, Heisteria

coushatta, Mespilodaphne............ 84

Rhamnus.

Coussapoa_._.

Cryptocarya wileoxiana

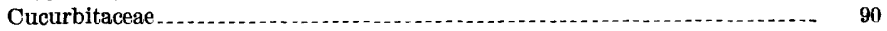

Cucurbites scrobiculatus

Dalbergia.....

eocenica ...... 83

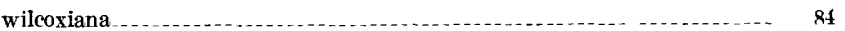

Dillenites microdentatus

Diospyros . . . .

Iniriflorianum

wilcoxiana

cf. D. miriflorianum...... 85,90 , pl. 23

Dodonaea wilcoxiana

drepanocarpoides, Leguminosites ........ 83,84, pl. 20

Dryophyllum puryearense
tennesseense.

Drypetes prelateriflora

E $\quad$ E

elaenoides, Myrica

elliptica, Schefflera

ellipticus, Sideroxylon ................. 84

emarginata, Cassia 
eocenica, Anemia

Bucida.

Canavalia

Capparis.

Dalbergia.

Paraengelhardtia

eocenicum, Gleditsiophyllum

eocenicus, Bombacites

Celastrocarpus

eulignitica, Anona

Carapa.

Coccolobis

Ilex

Mespilodaphne

Mimusops.

Nyssa...

Terminalia .

eoligniticus, Sapindu

Erythropalum

ettingshauseni, Engelhardtia

Eugenia

Euonymus splendens

europaeus, Glyptostrobus

Fagara piperitum

fagaraformis, Carpolithus

fayettensis, Cassia

ferrugineus, Celastrus

Ficus fructus rostrata

mississippiensis

myrtifolia

occidentalis.

pandurifolia .

pseudolmediafolia

pseudopopulus

puryearensis...

schimperi

tennesseensis

vaughani

wilcoxensis

Folindusia

formosa, Schefflera

formosus, Bombacites

Sapindus.

fructus, Ficus

Gardner, Julia, collection by

( lleditsiophyllum eocenicum

glenni, Cassia

Glyptostrobus europaeus

grandifolia, Psychotria

grayanus, Sabalites

gronovi, Carpolithus

guianensis, Heisteria

Heisteria.

acuminata..

costaricensis.

guianensis .

sapindifolia

Heterocalyx saportana

hilgardiana, Terminalia

Icacorea prepaniculata

Ilex eolignitica

inaequalis, Chrysobalanus

integrifolia, Artocarpus

Juglans occidentalis schimperi

K

kaulfussi, Lygodium...

Kentucky, localities in.

Kirn, A. J., collection by

kirni, Anacardium Artocarpoides

knowltoni, Rhamnites Sapindus.
Page

84

89 , pl. 21

83
83,84

83

84

84,85

$88-89$, pl. 22

83
84

83,84

85

84

83,84

83,84

85

85

83,84

88
85

89
, 85

85

87 83
84 84

84 84

G

84,85
$.83,84$

85

84

84,85

90

88 88

\section{5}

L

Page

aguncularia preracemosa

anceolatus, Mimosites

Ternstroemites

lancifolia, Nectandra

Laurus caudata

leei, Magnolia.

Leguminosae.

Leguminosites andiraformis

arachioides minor

drepanocarpoides

violensis

leptopus, Celastrus ...

essigniana, Artocarpus

Lexington, Tex., species from

linearifolius, Sapindus.

Liquidambar wilcoxianum

85

Lumnitzera.

Lygodium kaulfussi.

Lytle, Tex., list of species from

lytlensis, Ampelorissites

84

M

Tagnolia angustifolia

leei

major, Cassia glenni

Malpighiaceae

Mangifera

Melastomites verus

Meniphylloides tennesseensis

Mespilodaphne coushatta

eolignitica

Metopium wilcoxianum

microdentatus, Dillenites

milanensis, Calycites

Mimosites lanceolatus

variabilis

Mimusops eolignitica

sieberifolia

minor, Cclastrus

Leguminosites arachioide

miriflorianum, Diospyros

mississippiense, A pocynophyllum.

Cedrela

Ficus

Oreodaphne

Paliurus

Toraceae

Mount Pleasant, Tex., species from

mucronata, Sophora

Myrcia bentonensis.......... 83

vera

wortheni.

Myrica elaenoides.

puryearensis

Myrsinaceae...

83,84

yrtifolia, Ficus

(4) plon

parvula

pseudocoriacea . . . . . . .

puryearensis............. 84

wilcoxensis.. -

sp

nemorosus, Celastrus

$\begin{array}{ll}\text { Nyssa eolignitica } & 85 \\ \text { wileoxiana } & 84\end{array}$

obtusifolia, Oreodaphne

occidentalis, Ficus

Juglans

odoratifolia, Cedrela...

Olacaceae___ 87-88

Olax

Oreodaphne mississippiensis... 84

obtusifolia_._. 84,85

ovatum, A pocynophyllum mississippiense

Palaeodendron americanum 
Page

Palmocarpon butlerense

pandurifolia, Ficus.

Paraengelhardtia eocenica

parvula, Nectandra

Persea wilcoxiana

piperitum, Fagara

Poacites sp.

postnewberryi, Cinnamomum

praenuntia, Reynosia.

prelaterifiora, Drypetes.

prepaniculata, Icacorea.

preracemosa, Laguncularia

Proteoides wilcoxensis

Pseudima.

pseudimaformis, Carpolithus

pseudocoriacea, Nectandra

pseudolaurifolia, Banisteria

pseudomediafolia, Ficus

pseudopopulus, Ficus

Psychotria grandifolia.

pungens, Artocarpus

puryearense, Dryophyllum

puryearensis, Anecardites

Carpolithus

Cassia

Cedrela

Ficus..

Myrica..

Nectandra..

Putterlickia pyracantha

pyracantha, Putterlickia

ria

85

repandifolia, Banisteria

Sophora

Reynosia praenuntia longepetiolata

Rhamnites knowltoni.

Rhamnus coushatta.

ricida, Artocarpus

Roberts, J. K., collections by

robertsi, Anona

$$
\text { Celastrus. }
$$

83,84, pl. 20

80
84

Ceta, Ficus fructus

rotundifolia, Vit is

rupestris, Celastrus.

Sabalites grayanus

saffordi, Banksia.

Sapindaceae

sapindifolia, Heisteria

forndus eoligniticus.

formosus

knowltoni.

linearifolius

mississippiensis

$83,84, \mathrm{pl} .23$

84

83,84

\section{R}

86. pl. 21

83,84
Page

elliptica

formosa

schimperi, Ficus

Juglans......................... 84,85

scrobiculatus, Cucurbites............ 23

Sideroxylon ellipticus

sieberifolia, Mimusops

Sophora mucronata

repandifolia

wilcoxiana .......... 84,85

splendens, Euonymus...
Spondias. $\ldots \ldots \ldots \ldots$

Stewart, Glenn, collection by

torinensis, Celastrus.

ennesseense, Dryophyllum

tennesseensis, Ficus . . . . . .

Meniphylloides.

Terminalia eolignitica.

hilgardiana

Ternstroemites lanceolatus.

Tetrastigma .

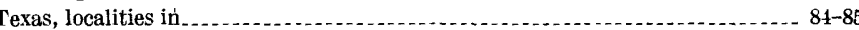

Vantanea wilcoxiana

variabilis, Mimosites . . .

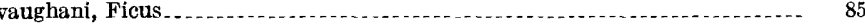

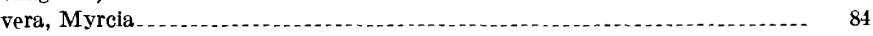

verus, Melastomites_.......... 23

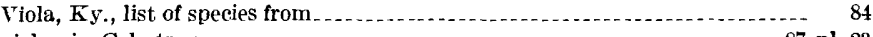

violensis, Celastrus $\ldots \ldots \ldots$.

Leguminosites

Vitaceae

Vitis

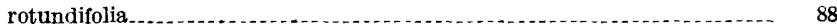

W

Wickliffe, Ky., list of species from ............... 83

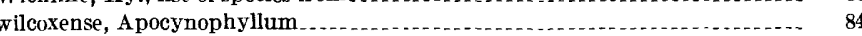

Conibretum . . . . . . .

wilcoxensis, Artocarpoides. . . .

Ficus. ........ 84

Nectandra

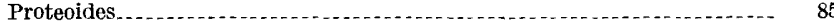

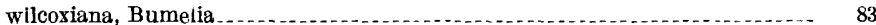

Cryptocarya $\ldots$

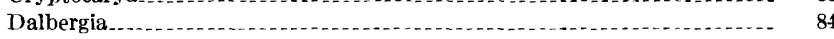

Diospyros ............................................................ 84

Dodonaea

Nyssa $\ldots a_{1}$

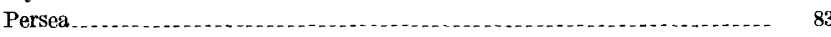

Sophora $\ldots 1 . \ldots 1$

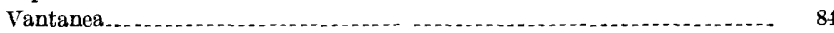

wilcoxianum, Liquidambar

Metopium.

wortheni, Mvrcia 
